\title{
INTRODUCTION OF THE UNIFIED COMMUNICATIONS INFORMATION SYSTEM E-112
}

\author{
Drage T. Petreski ${ }^{\mathrm{a}}$, Andrej P. Iliev ${ }^{\mathrm{a}}$, Aleksandra D. Petreska ${ }^{\mathrm{b}}$ \\ "Military Academy „General Mihailo Apostolski“, Skopje, \\ Republic of Macedonia, \\ e-mail: drage_petreski@yahoo.com, andrej220578@gmail.com \\ ${ }^{b}$ Faculty of Electrical Engineering and Information Technologies, \\ Skopje, e-mail: petreska_aleksandra@yahoo.com
}

FIELD: Defense Management, Crisis Management

DOI: 10.5937/vojtehg63-6818 ARTICLE TYPE: Professional Paper ARTICLE LANGUAGE: English

\section{Abstract:}

The introduction of the European emergency number 112 in the Republic of Macedonia should provide benefits that will be implemented and regulated in accordance with the European legislative framework. This number has already provided numerous benefits to all member states of the European Union. Its implementation should be supported by the introduction of the latest technology information and communication solutions, hardware and software solutions tailored to the situation in the country. It will replace four current phone numbers for emergency calls that are a responsibility of the Ministry of Interior (192), local fire units (193), emergency care (194) and the Center for Crisis Management (195). These numbers are planned to be replaced by the European emergency number 112 together with its full implementation into the integrated information - communication center.

Key words: European number 112; solutions; information systems; implementation; countries; communities; benefit; unification.

\section{Introduction}

The introduction of the European emergency call number $E-112$ is one of the major projects which are implemented by the Centre for Crisis Management of the Republic of Macedonia, based on the Law for Crisis 
Management of the Republic of Macedonia (Official Gazette, 29/2005), Amending the Law for Crisis Management (Official Gazette, 36/2011) and the Law for Electronic Communications (Official Gazette, 39/2014).

The Center for Crisis Management is the most responsible state body for the implementation of the single communication information system for emergency calls E-112. This project is an inter-ministerial activity which will be realized and implemented in cooperation with various entities in our state that have responsibilities in this segment.

The first phase of the task is completed, which includes the activities of the inter-agency project and the responsibilities of several state bodies. The activities of the second phase include fully implementing and introducing the use of E-112 and also the tasks that cover the part of the state administration.

The introduction of the use of this number is the duty and obligation of every country-candidate for a membership in the European Union, which, at the time for obtaining a status for a country member of the EU, should have introduced this number in operational use.

The Agency for Electronic Communications based on a Plan for public communications networks and services in the Republic of Macedonia (Official Gazette, 143/2009) has adopted Decision No. 07-588/4 from 25.05.2012, which represents the main legal regulations for awarding this number to the Center for Crisis Management of the Republic of Macedonia.

Besides the current phone numbers for emergency calls, closely related to number 112 are: Law for Fire Protection, Law for Health Insurance, Law for Protection and Rescue, Police Law and the competencies of several NGOs.

One of the reasons for introducing 112 into many countries around the world represents the growing efforts of relevant departments to deal with many risks that took place in the past as well as in the present.

Generally speaking, the world has shown very serious institutional and organizational weaknesses, especially in the protection of population, environment and material wealth during frequent accidents, hazards and disasters. Precisely for these reasons, both at the national and international level, developed states, first on their own and then united with other states, made efforts to strengthen their own capacity building and skills for quick and more efficient response to possible dangers. People are increasingly faced with non-traditional forms and types of risks such as: global terrorism, drug trafficking, illegal weapons, dangers from weapons of mass destruction, infectious diseases and epidemics of large-scale, unemployment, poverty and other social problems, consequences of global climate change, natural disasters, environmental degradation, technical and technological disasters, industrial hazards and other dangers. 
In all these challenges, there is an active participation of international organizations such as: United Nations (UN), European Union (EU) and NATO, which through their institutional mechanisms, specific measures and actions plan preventive measures to reduce the risks of disasters worldwide. The decade of $2005-2015$ is a period of strengthening the resilience of many NATO and EU countries.

By adopting the concept of National Security and Defense, they expressed the need for the construction of a new modern system which provides a higher level of security and protection of citizens and their property. The establishment of the system will achieve a full and complete compatibility and interoperability with most European and global security systems. Among other things, the purpose and the basic function of this system are the terms of prevention, early warning and dealing with all the possible risks and hazards, providing faster and more efficient response for their elimination. (Official Gazette, 40/2003).

The basis of the whole system is providing a consistent level of coordination, cooperation and communication of all relevant entities, ongoing assessment of the risks and dangers as well as fast, timely, complete and effective response to all relevant entities with appropriate use of available resources in states.

We are witnessing a number of changes and amendments to EU legislation, harmonization and improvement of the characteristics and standards of the national legislation with the EU. The imperative for the implementation of the universal European emergency number 112 is a necessary requirement for prospective countries wishing to join the EU. The telephone number 112 is a universal number constantly updated and upgraded with standards that represent a new generation of 112 , with applying the best practices that have taken the best and the most efficient models in Europe that are incorporated as a standard.

\section{Characteristics of emergency call numbers}

The organization and functioning of all current phone numbers for emergency calls are established trough 24-hour shifts with the following telephone numbers: 192 - phone number for emergency calls to the Ministry of Interior, 193 - phone number for emergency calls to territorial units for fire protection 194 - phone number for emergency calls of medical assistance and 195 - phone number for emergency calls to the Centre for Crisis Management in the RM. This is available with free dialing from all means of telecommunications (fixed and mobile telephony) covering the whole territory of the Republic of Macedonia, 24 hours and 365 days of the year.

All four phone numbers for emergency calls at this time are organized and operate without a full and complete telecommunication and information 
connectivity, without a possibility of automatic switching - routing the call from one service to another, although they cooperate with each other manually.

The organization and operation of the state bodies, administration and the 35 regional offices of the organization that cover all the territory are divided into eight planning and statistical regions.

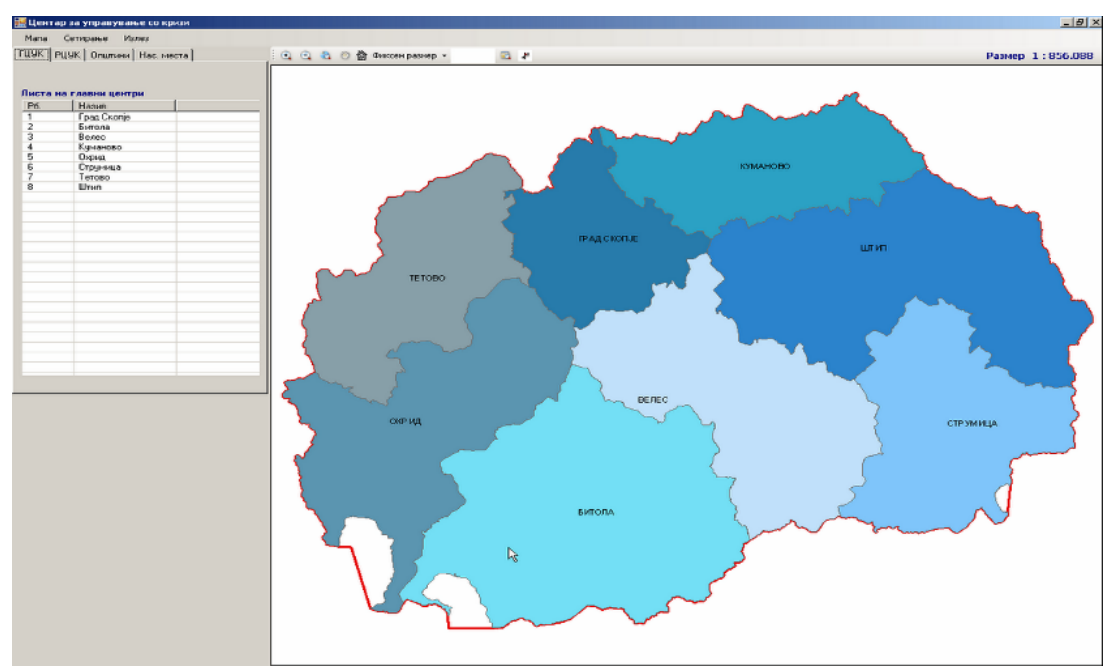

Figure 1 - Organization model with eight departments in CMC and MOI Slika 1 - Organizacioni model sa osam sektora u CUK i MUP

Puc. 1 - Организационная модель, объединяющая 8 департаментов ЦКС и МВД

The coverage and the ability to dial the phone number 195 from any place in the Republic of Macedonia is provided through one of these eight operating centers and an emergency response will be provided to each call.

According to the Regulation on the type of data and information on the manner and procedure for their submission to the Center for Crisis Management, through the State duty operational center in Skopje, the information from all major regional centers, institutions (government and private) is shared at a local and national level, as well as to nongovernmental organizations and civic associations. After preparing a national report or daily information on the current situation, they forward this information to the Government, relevant ministries, government departments and agencies, international institutions in the country, some embassies and other state institutions (Official Gazette, 09/2007).

The emergency number 195 of the Center for Crisis Management is commonly used in cases of emergency which is not directly related to one of the emergency services of police, fire department or emergency medical service assistance. Typical cases of the emergency number 195 are the interruption of power supply, water supply problems, large snowfalls, technical or environmental accidents or explosions and other hazards. 


\section{Ability to integrate telephone numbers for Emergency calls in a single emergency number}

The operating center for the emergency calls E-112 will have a major impact with each other telecom operators. They will have an impact on standards and characteristics to meet the E-112, and that will be a selection of the best and most suitable service providers. Telecom operators should be obliged to deliver all existing calls to the emergency numbers 192, 193, 194 and 195 and the new 112 number directly to the center for emergency calls. Telecom operators will also have a responsibility to deliver additional information for each call, such as information on the caller's location.

There are currently more mobile telecom operators such as: T-Mobile, owned by Deutsche Telecom, ONE owned by Slovenia and Austria and VIP. Land line operators are: Macedonian Telecom partly owned by Deutsche Telecom, NeoTel of NeoComm, ONE -Slovenija, Blizoo-Fiber Power and other operators in accordance with the provision of electronic communications services for citizens which can use the interconnection services to other operators (Official Gazette, 39/2014).

Communication systems are organized and function in this moment by operators for telephone numbers for emergency calls in Macedonia with: Tetra system, analog radio systems and mobile telephony - GSM, fax and landline phone lines.

Previously listed phone numbers for emergency calls $(192,193,194$ and 195), which are currently operating in the country, are phone numbers that are functioning independently and they are not connected to a common communication system. They have no common communication support, collaboration and joint automatic dispatching. The large percentage of the capacity of telephone numbers cannot respond in case of major hazards and risks arising in the country, which is especially the case with the capacity of the telephone number 195.

\section{European emergency number 112}

For dealing with risks and hazards presenting danger to the population, a crises management system has been organized for prevention and early warning activities which pose a risk to the property, health and life of humans and animals and other risks and hazards that directly threaten the constitutional order and security of the Republic of Macedonia, or a part of it. According to the Law for Crisis Management, this includes information gathering, assessment, situation analysis, setting goals and objectives, developing and implementation of the necessary actions for prevention, early warning and crisis management (Official Gazette, 29/2005 and the Official Gazette, 36/2011). 
The Center for Crisis Management is a professional, organizational and administrative support to the two bodies of the Government - the Steering Committee and the Assessment Group. Pursuant to Article 40 of the Law for Crisis Management, the Center is an independent state authority with a responsibility for the implementation of the European emergency number $\mathrm{E}-112$. The establishment of $\mathrm{E}-112$ and the introduction of a single emergency number in Macedonia in accordance with the Law for Crisis Management is regulated and determined necessary by Chapter $\mathrm{V}$ in Articles 37 to 41 in the National Law to ensure continuous communication, coordination and cooperation in collecting data and information, analysis, and submission information about the risks and dangers that may threaten the security of the state. In order to provide timely actions of all relevant agencies, including all the necessary and available resources, it is necessary to fulfill one of the important criteria - the functioning of 112 . Therefore, the Crisis Management Law has to deal with the introduction, application and development of a geographical information system.

The implementation of the E-112 is an obligation and a right for the users of electronic communications networks and services in the EU member states, which are required to implement the single European emergency number E-112.

The Republic of Macedonia is interested in introducing the use of the European emergency number and complies with current European standards.

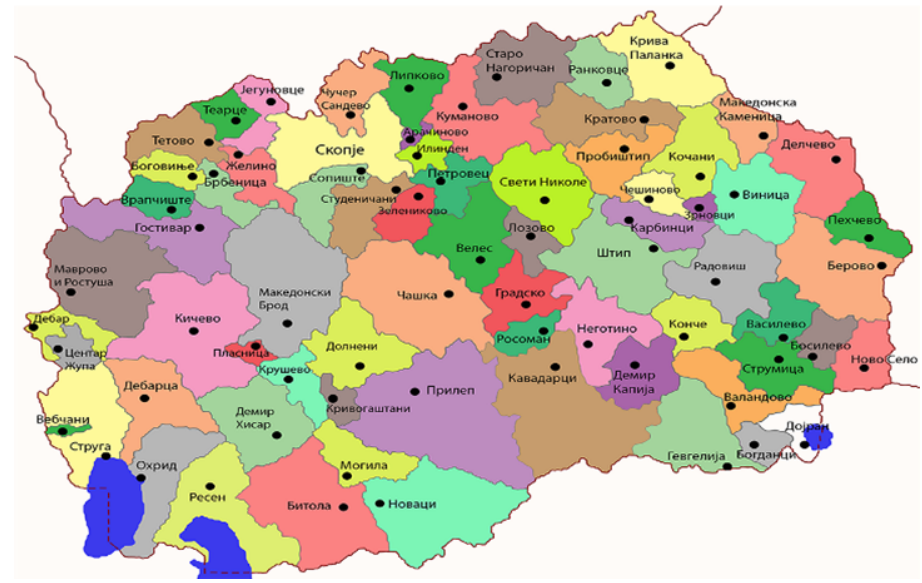

Figure 2 - The territorial division of the Republic of Macedonia Municipalities Slika 2 - Teritorijalna podela Republike Makedonije po opštinama

Puc. 2 - Административно-территориальное деление Республики Македония

Introducing the European emergency number 112 in each country involves numerous activities such as popularization, informing the population and residents throughout the state with the role, tasks and the objective which must be achieved as well as the obligations for holders of 
implementation before its introduction into service. Awareness of the public and all citizens has a crucial importance for better and more efficient operating. (Official Journal of the European Communities, 108/51, 2002), (Official Journal of the European Communities, L337/11, 2009).

Informing all the categories of people and state institutions is important for the representatives of 81 units of local self-government and municipalities in the country.

With introducing the use of this number, The Republic of Macedonia will have to mark the European Day of 112 and also a holiday which is February 11th. It should be another interesting event to promote the tasks and the role of 112 .

People learn about the possibility of using 112 as an important tool for getting SMS messages to the mobile device when they enter the country. It is a daily practice that can be seen on entering each of the EU countries. A feasibility study of the characteristics of the Macedonian situation provides the basic tasks and functions that will attain 112. These include emergency services and assistance such as police, fire protection units, Emergency Department, Directorate for Protection and Rescue Center, crisis management and additional AMSM - Office road assistance, Customs Agency for Electronic communications and other services. Popularization and introduction of the role of each of these services is also in citizens' interest.

The majority of EU normative acts are related to the European Association for Emergency Numbers - EENA, which has its own role and the responsibility to assist countries in adaptating and implementing international normative acts of the European Union and the competent committee.

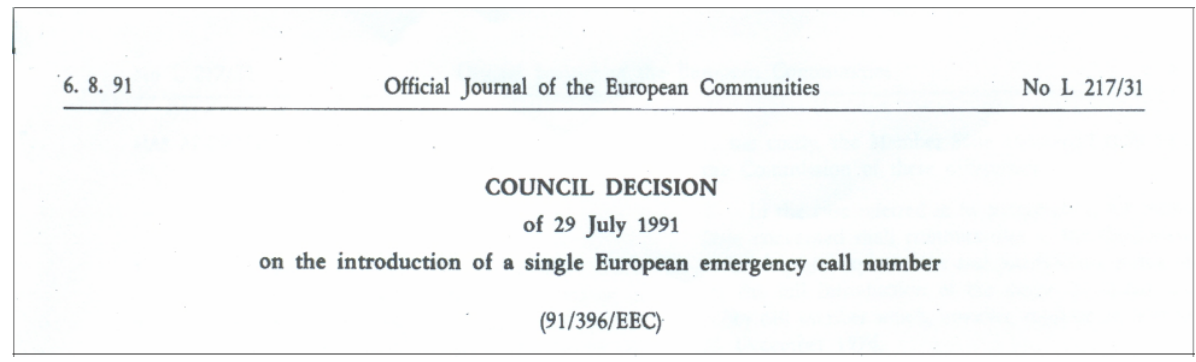

Figure 3 - EU Official Journal introducing the use of E-112

Slika 3 - Službeni list Evropske unije za uvođenje u upotrebu E-112

Puc. - Официальный журнал ЕС, Директива «Системы Е-112»

(The Council of the European Union, Council Decision 91/396/EEC, Official Journal of the European Communities, L 217/31, 1991). The international norm related to this topic gives many international decisions, directives and regulations, requiring that all EU member states ensure that the number 112 is used in public telephone networks as a single European emergency number (http://www.eena.org). 
The Member States were asked to introduce the single European emergency number 112 for their emergency services to be more accessible to all people in need of emergency assistance. The single European emergency number 112 works in parallel with the existing national numbers in most of the countries and must not replace the existing national emergency numbers.

Each year, Europeans make around 1.25 billion journeys in different forms in the European Union. That means that a large number of travelers may face emergencies and may need help from (EENA Operations Document Multilingual 112 Calls, 2012).

There are more than 200 million migrants in the world. Europe receives the largest number of migrants - about 70.6 million people (International Organization for Migration, 2005).

These are numbers that cannot be ignored because it is necessary to have an effective, publicly recognized, connected and accessible organization or service that will answer to all these possible requirements.

Remembering different phone numbers in different countries was a problem for travelers especially when their safety or life was threatened and they required assistance. The compatibility of standards in all countries will enable all people to get assistance no matter where they are.

The EENA is a European association founded in 1999, dedicated to promoting the provision of high quality services in emergency cases, which are obtained through the number 112. It assists and provides services in determining the manner of organization and management in case of emergency and the use of 112. It promotes solutions of various EU Member States that develop different models of organization and functioning of 112. It assists in quality solutions and emergency responses of competent bodies and services.

It helps bringing national and international laws in all countries.

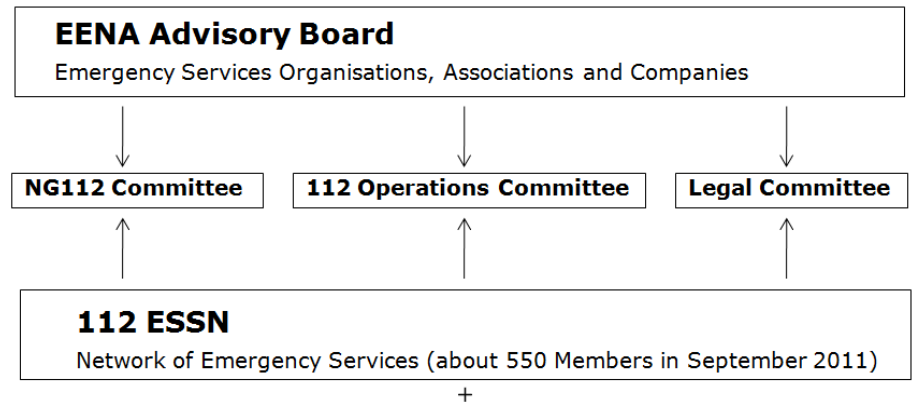

MEPs 112 Champions

Members of the European Parliament promoting 112 issues in the European Parliament Committee

Figure 4 - Structure of the European association EENA Slika 4 - Struktura evropske asocijacije EENA

Puc. 4 - Структура Европейской ассоциации экстренных служб EENA 
The EENA helps promoting and establishing effective systems for reporting emergencies to citizens. The EENA membership includes the access to about 630 different associations for emergency services, represented by more than 40 European countries, 50 different solutions organizations, other international organizations and associations, and $28 \mathrm{Mem}-$ ber States of the European Union and Parliament (EENA Operations Document 112 Accessibility for People with Disabilities, 2012).

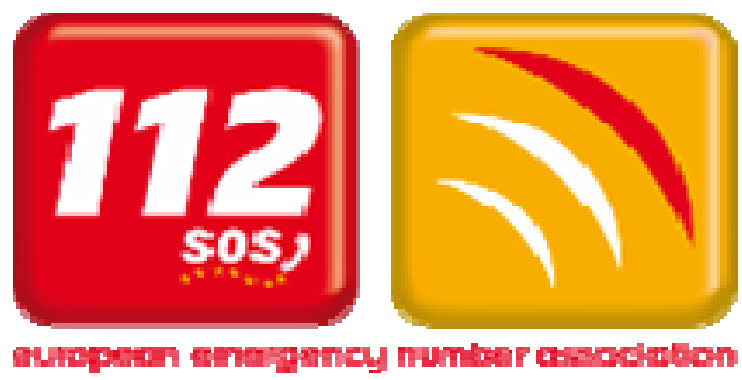

Figure 5 - The symbol of the EENA -112 Associations Slika 5 - Simbol EEHA - 112 udruženja

Puc. 5 - Логотип EENA - 112 (Единый номер экстренной службы)

In its work, the EENA brings relevant agencies, state authorities, individuals and organizations together. The Advisory Board (Advisory board of EENA) brings together politicians, associations, international organizations and those who provide solutions aimed at implementing and improving the chain of network E-112 for emergency services of individuals or services which can strengthen the public services in shared experiences and best practices shown (Communications Committee, Implementation of the European emergency number 112, 2014).

With 112, the Members of European Parliamenthave a network dedicated to promoting better communication between competent authorities as well as between citizens in case of danger and urgency.

The EENA annually holds round tables, conferences, workshops, and video conferencing with invitations to participants to share and exchange their experiences.

Last year the conference was held in Riga - Latvia and this year the conference was held in Warsaw, Poland, from 02-04 April 2014. The exchange of different national experiences, suggestions and solutions is available on the Internet site of the EENA for all its members. It is an opportunity to identify and share lessons learned from different countries and authorities.

The last major activity conducted by the EENA is introducing a new standard of an agreed call. So far this has been an agreed pilot project in eight Member States of the EU, which started last year with the 
implementation of this new project as a pilot standard. This project proposes the establishment of requirements for all vehicles in traffic to install a modem, which would, in case of an accident and collision, immediately and automatically send a signal to the center of the E-112 to the emergency response and rescue team (Caller Location in Support of Emergency Services, Next Generation 112, 2012). The implementation of this project is to help and to mitigate the consequences of severe accidents in the EU. Automatic dialing of any vehicle that has suffered a serious car accident through the center 112 will become operational by the end of 2015. It needs to enable full compatibility, interoperability and continuity equally to all member states and it should be an improvement in road security systems to help and prevent loss of lives and injuries (EENA Operations Document - Caller Location in Support of Emergency Services, Next Generation 112 (NG112) - Introduction to Next Generation Emergency Services in Europe, [Internet], Available at: http://www.eena.org/pages/ng-112).

\section{Achieved level of introducing the E-112 in the Republic of Macedonia}

On the basis of the international tender from August 2008, a feasibility study for the E-112 in RM has been prepared. The study has been produced by a chosen consulting company, Herman Buehler $\mathrm{GmbH}$ from Austria. It incorporates features that need to be fulfilled for the introduction of the E-112 as well as the course and characteristics of the implementation of the $\mathrm{E}-112$.

The Government set up a Steering Committee to supervise the feasibility study prepared by the consulting company, which was composed of members from relevant government entities - Center for Crisis Management, Ministry of Interior, Ministry of Health, Ministry of Transport and Communications, Directorate for protection and Rescue, Agency for Electronic communications, etc. The feasibility study was approved by the Government.

The information for the final report of the Supervisory Board to supervise the Feasibility Study System Emergency E-112 of the Republic of Macedonia was that two stages were planned in the 112 implementation. The first phase was the conceptual definition of the E-112, while the second stage was the implementation of the E-112. Since the adoption of the feasibility study, several possible options have been proposed on how the Macedonian model will be functioning. The organization and the decision on accepting the best model for the organization and functioning of the E-112 operating center are shown in this figure. 


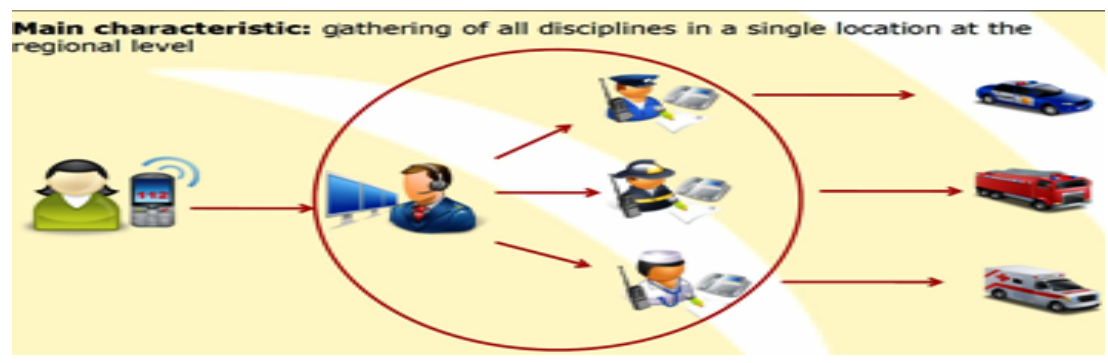

Figure 6 - Proposed and adopted solution for the organization of 112 in the RM according to the Feasibility Study

Silka 6 - Predlog i usvojeno rešenje za organizovanje 112 u RM Prema Fizibiliti studiji

Рис. 6 - Решение по организации системы E-112 на территории Республики

Македония, согласованное с технико-экономическим обоснованием

The implementation of the E-112 will need to cover all the latest and final solutions of the full technology infrastructure installed in the hardware and software systems and necessary equipment.

The feasibility study was provided based on three regional operating centers and emergency calls in: Skopje, Stip and Prilep. The Center for Crisis Management will have the same infrastructure software, hardware and connectivity as well as these three operational centers, for full and complete logistical, technical, professional and administrative support to the Steering Committee and the Assessment Group, as separate bodies of the government in case of major risks and possible disasters.

The image below provides the coverage of the zones of three operational centers in Skopje, Stip and Prilep. In case of the interruption of work for any reason in any of these centers, the other two operational centers will be able to take over work for its territory and population. This is a "back up" solution for full and complete coverage in case of emergency. In such cases, there is an opportunity to divert calls by operators.



Figure 7 - Situation in the Operating centers E-112 in the Republic of Macedonia Slika 7 - Postavljenost operativnih centara E-112 u Republici Makedoniji Puc. 7 - Места расположения оперативных пунктов системы E-112 на территории Республики Македония 
The modern E-112 communication and information system also includes a sophisticated Geographic Information System - GIS. It is dealt with in Chapter $\mathrm{V}$ of the Law for Crisis Management, under the heading on communication and coordination which is related to the $\mathrm{E}-112$ communication and information system (Official Gazette, 29/2005 and Official Gazette, 36/2011).

The development and application of the technology for the Geographic Information System - GIS started in 2008. Devastating fires in 2007 indicated a need to use this modern method for spatial presentation and overview of conditions and events, with a detailed map showing the location of the closest available units and decision makers in rescue activities. The platform will be based on a software system and GIS server tools for the development of desktop applications for data entry in the geodatabase and a WEB application browser. The purpose of this is to accelerate and systematically improve the access to information to the Center for Crisis Management and to create daily analyses.

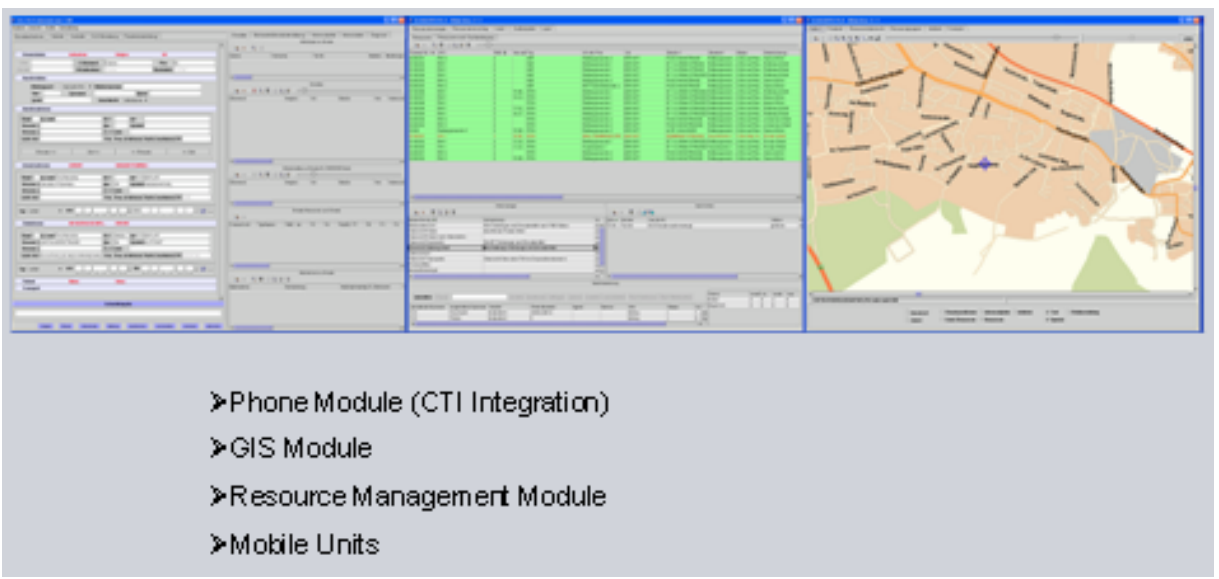

Figure 8 - Models of three monitor displays depending on the E-112 operator's needs Slika 8 - Model prikazivanja događaja prema potrebi operatora E-112

Puc. 8 - Модели происшествий, выведенные на монитор диспетчера системы Е-112

Figure 8 shows the features of the software model for filling an E112 event report, the base management and resources of the E-112 for the event location, as well as the geographic information system with a detailed map and the location of the closest available units.

The Center for Crisis Management should have a key role in providing the fastest, most efficient and comprehensive way of intervention of all relevant operating entities in order to ensure the use of appropriate resources required proportionally to the intensity, severity and nature of the threat.

The basic requirements are met by introducing the use of the E-112 emergency number. Meeting the prescribed European standards should be specified in the national laws through harmonizing all services involved with current phone numbers for emergency calls with E-112. 


\section{Conclusion}

This inter-ministerial project of the Republic of Macedonia for its candidate status in NATO and the EU is mandatory.

A single phone number for emergency E-112 is simple, easy-tomemorize, popularized not only by the EU Member States, but also in our country. The project implementation and financial implications will be around six to seven million euros.

Functioning with a reduced number of employees in comparison to the current situation with a united service for emergency calls will be the final benefit for more effective work and financial savings that will be achieved.

The experiences in the 28 EU Member States that have implemented a variety of ways consistent with their national and required European standards gave positive effects. It can be noticed that, except for the emergency call number E-112, there are other national numbers. Only in these six countries: Denmark, Finland, Iceland, Netherlands, Romania and Sweden, the number E-112 exists as a single emergency call number (EENA NG 112 Document, Next Generation 112 Long Term Definition, [Internet], Available at: http://www.icpem.net/LinkClick.aspx).

This project has also been introduced in the countries such as: Serbia, Montenegro, Bosnia and Herzegovina, Croatia and other states but without meeting any standards.

Accepting the solution applied in the majority of the countries on the European continent, and achieved compatibility with all these countries is a sufficient argument for this project to be implemented as soon as possible in order to bring all the benefits in increased security for the citizens and protection of material goods.

\section{References}

Communications Committee, 2014, Implementation of the European emergency number 112 - Results of the seventh data-gathering round, Brussels, European Commission.

EENA Operations Document - Multilingual 112 Calls, [Internet], Available at: <http://www.eena.org/ressource/static/files/2012_01_25_3-1-4_mic_v1.0_abstract.pdf>, Accessed: 04.01.2014

EENA NG 112 Document, Next Generation 112 Long Term Definition, [Internet], Available at:

http://www.icpem.net/LinkClick.aspx?fileticket=eG_L4iePOus\%3D\&tabid=107\&mid=588, Accessed: 04.01.2014

EENA Operations Document - 112 Accessibility for People with Disabilities, [Internet], Available at:

http://www.eena.org/uploads/gallery/files/operations_documents/2012_01_13_112access ibilityforpeoplewithdisabilities.pdf, Accessed: 24.01.2013

EENA Operations Document - Caller Location in Support of Emergency Services, Next Generation 112 (NG112) - Introduction to Next Generation Emergency Services in Europe, [Internet], Available at: <http://www.eena.org/pages/ng-112>, Accessed: 23.01.2013 http://www.eena.org 
International Organization for Migration, 2005, World Migration 2005, Geneva, International Organization for Migration.

Official Gazette of the Republic of Macedonia, 40/2003, Conception for national security and defence, Skopje, State Enterprise "Official Gazette".

Official Gazette of the Republic of Macedonia, 29/2005, The Law for Crisis Management, Skopje, State Enterprise "Official Gazette".

Official Gazette of the Republic of Macedonia, 09/2007, Regulation for type of data and information on the manner and procedure for submission to the Center for Crisis Management, Skopje, State Enterprise "Official Gazette".

Official Gazette of the Republic of Macedonia, 143/2009, Plan for public communications networks and services in Republic of Macedonia, Skopje, State Enterprise "Official Gazette".

Official Gazette of the Republic of Macedonia, 36/2011, Amending Law for the Crisis Management, Skopje, State Enterprise "Official Gazette".

Official Gazette of the Republic of Macedonia, 39/2014, Law for Electronic Communications, Skopje, State Enterprise "Official Gazette".

Official Journal of the European Communities L217/31, 1991, The Council of the European Union, Council Decision 91/396/EEC on the introduction of a single European emergency call number, Brussels.

Official Journal of the European Communities, L108/51, 2002, The European parliament and the Council of the European Union, Directive 2002/22/EC on universal service and users' rights relating to electronic communications network and services.

Official Journal of the European Communities L337/11, 2009, The European Parliament and the Council of the European Union, Directive 2009/136/EC.

\section{ВНЕДРЕНИЕ ЕДИНОЙ КОММУНИКАЦИОННО- ИНФОРМАЦИОННОЙ СИСТЕМЫ Е-112}

ОБЛАСТЬ: управление защитой, кризис-менеджмент

ВИД СТАТЬИ: профессиональнная статья ЯЗЫК СТАТЬИ: английский

Краткое содержание:

Внедрение единого европейского номера 112 по экстренным происшествиям на территории Республики Македония будет произведено в соответствии с европейскими стандартами и законодательными актами EC, с целью улучшения системы защиты населения.

Преимущество внедрения единого номера 112 по экстренным происшествиям подтверждены Советом Европы и введением данной инфрормационно-коммуникационной системы странами Евросоюза.

Внедрение данной системы должно поддерживаться новейшими компьютерными технологиями и прогрессивным программным обеспечением, согласованными с возможностями государства.

Необходимо объединить существующие телефонные номера по экстренным происшествиям, такие как: Министерство 
полиции (192), Пожарной охраны (193), Скорой медицинской помощи (194), Центра управления в кризисных ситуациях (195).

Планируется заменить существующие номера по экстренным происшествиям единым европейским номером 112, интегрированным в общую информационно-коммуникационную систему Евросоюза.

Ключевые слова: единый европейский номер E-112, решение, информационная система, внедрение, страны, сообщества, польза, объединение.

\section{UVOĐENJE JEDINSTVENOG KOMUNIKACIJSKOG} INFORMACIONOG SISTEMA E-112

OBLAST: menadžment u odbrani, krizni menadžment VRSTA ČLANKA: stručni članak JEZIK ČLANKA: engleski

\section{Sažetak:}

Uvođenje evropskog broja za hitne događaje 112 u Republici Makedoniji treba da omogući poboljšanje, koje će biti implementirano, uređeno i u saglasnosti sa evropskom zakonodavnom regulativom. Dokaz za to jesu brojni benefiti ostvareni tokom višegodišnjeg postojanja broja 112 u državama članicama Evropske unije. Ovaj broj predstavlja integrisanu i jedinstvenu funkcionalnu i informatičko-komunikacijsku celinu. Njegovo uvođenje treba da bude podržano najnovijom tehnologijom informatičko-komunikacijskih rešenja, hardverske opreme, kao $i$ softverskih rešenja prilagođenih uslovima države. Biće objedinjena sadašnja četiri telefonska broja za hitne događaje, koji su pod kontrolom Ministarstva policije (192), lokalnih protivpožarnih jedinica (193), Hitne medicinske pomoći (194) i Centra za upravljanje krizom (195). Predviđa se da brojevi budu zamenjeni uključivanjem u rad i potpunom implementacijom evropskog broja za hitne događaje 112 u integrisan informatičko-komunikacijski sistem.

Ključne reči: evropski broj E-112, rešenja, informacioni sistemi, izvršenje, zemlje, zajednice, korist, ujedinjenje.

Datum prijema članka / Paper received on / Дата получения работы: 27. 09. 2014. Datum dostavljanja ispravki rukopisa / Manuscript corrections submitted on / Дата получения исправленной версии работы: 27. 10. 2014.

Datum konačnog prihvatanja članka za objavljivanje / Paper accepted for publishing on / Дата окончательного согласования работы: 29. 10. 2014. 